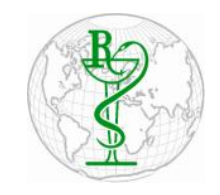

INDO GLOBAL JOURNAL OF

PHARMACEUTICAL SCIENCES

ISSN 2249- 1023

\title{
Therapeutic Spectrum of Bacterial Metabolites
}

\author{
Rajeev K Singla ${ }^{1}$, Harsh D Dubey ${ }^{2}$, Ashok K Dubey ${ }^{1 *}$ \\ ${ }^{1}$ Division of Biotechnology, Netaji Subhas Institute of Technology, Sector-3, Dwarka, New Delhi-110078, India \\ ${ }^{2}$ Faculty of Medicine, Nursing \& Health Sciences, Monash University, Clayton, Victoria 3800, Australia
}

Address for Correspondance: Ashok K Dubey, adubey.nsit@gmail.com

\begin{abstract}
Bacterial metabolites have been immensely useful as antibiotics, hence most of the work on the subject revolved around understanding their antibiotic properties. However, it emerged from current literature that they are pleotropic in nature as they express a broad array of activities with potential therapeutic significance. These characteristics include, but are not limited to anticancer, antiviral, antitrypanosomal, antidiabetic adjuvants, anti-inflammatory, hepatoprotective etc. A structural classification of the bacterial metabolites has been given based on the structures re-drawn from the published data. Role of the structural motifs, thought to be primarily present in fungal and plant (eukaryotic) metabolites but now reported in bacterial metabolites as well, have been discussed in light of their multifaceted activities. An analysis of the current literature pertaining to diverse therapeutic properties of the bacterial metabolites is presented. ( 2014 iGlobal Research and Publishing Foundation. All rights reserved.
\end{abstract}

KEYWORDS: Microbial Metabolites; Secondary Metabolites; Pharmacological Activity; Bioactive Agents; Therapeutic Diversity.

\section{INTRODUCTION}

Prokaryotic microorganisms are known to produce a large number of secondary metabolites. While these compounds help the producing organisms to survive under unfavorable conditions, they are not always essential for growth and reproduction. Many of these metabolites have been known to possess antimicrobial properties. Such activities may provide an edge to the producing organism in the competition for food and space in its habitat. Additionally, these metabolites may have other significant roles in the biology of the organism; however, this area requires further studies.

Actinomycetes represent one of the most prolific sources for antibiotics. Arguably one of the most potent tools in the hands of modern medicine, antibiotics have and continue to save millions of human lives from infectious diseases. While the first antibiotic to be discovered and used in treatment of infectious diseases came from the fungus, Penicilium notatum [1], much of the subsequent discovery of new and novel antibiotics was within the genus Streptomyces of actinomycetes group [2]. Enormous progress has since been made in understanding the structure and function of various antibiotics with regard to their cidal or static affects on pathogens. Besides the actinomycetes group of prokaryotes, other bacterial genera, for example, Bacillus, Pseudomonas etc. were also found to produce several secondary metabolites with strong anti-fungal and anti- bacterial activities [3].

The immense metabolic diversity among the bacterial population from different ecological habitats is a well recognized fact. This attribute confers the ability upon microbes to cope with a range of adverse conditions, thereby facilitating the adaptation required to thrive under such conditions. During such phases of their life cycle, microbes produce a large number of secondary metabolites. The primary function of these metabolites is to mediate critical functions in the life cycle of the producing organism under the given conditions. However they have also been demonstrated to possess varied properties of potential therapeutic applications, such as, anti-diabetic adjuvant [4,5], anti-oxidant [6], antiinflammatory [7,8], anti-cancer [9-13], enzyme inhibitors [14], immunosuppressents [15], immunostimulant [16], antitrypanosomal [17] etc.. While these properties of plant 
Indo Global Journal of Pharmaceutical Sciences, 2014; 4(2): 52-64

secondary metabolites are well characterized [18-21], the therapeutic spectrum of the bacterial secondary metabolites is not yet thoroughly explored. But a resurgence of interest in the pharmacological properties of bacterial metabolites is evident in the scientific community as shown by several recent publications. Accordingly, the purpose of this review article is to present a summary of the current literature within this rapidly growing field. Also, structural classification of bacterial metabolites has been framed in an attempt to somewhat simplify further studies on their structure-function relationships towards establishing the diverse therapeutic potential of these compounds.

\section{STRUCTURAL DIVERSITY OF BACTERIAL METABOLITES}

There is an intricate relationship between the structure and function of biomolecules. This implies that the functional diversity must be accompanied by structural diversity. Accordingly, understanding the structure of the bacterial metabolites will be of immense significance in establishing their multifaceted therapeutic properties. Guided by these ideas, we have collected structure and relevant literature for several secondary metabolites from bacteria. Various examples of bacterial metabolites along with their sources have been provided in Table 1.

Table 1. Various bacterial metabolites with antimicrobial activities and their sources.

\begin{tabular}{|c|c|c|c|}
\hline Antimicrobial Agent & Figure & Source & Reference(s) \\
\hline Cyclo-( $L$-Leu- $L$-Pro $)$ & $1 \mathbf{a}^{\mathrm{a}}$ & Bacillus pumilus & 17 \\
\hline 3-hydroxyacetylindole & $1 b^{a}$ & Bacillus pumilus & 17 \\
\hline$N$-acetyl- $\beta$-oxotryptamine & $1 c^{\mathrm{a}}$ & Bacillus pumilus & 17 \\
\hline cyclo-(L-Phe- $L$-Pro $)$ & $1 d^{\mathrm{a}}$ & Bacillus pumilus & 17 \\
\hline 3-formylindole & $1 \mathrm{e}^{\mathrm{a}}$ & Bacillus pumilus & 17 \\
\hline Sulfazecin & $1 \mathbf{f}^{\mathrm{a}}$ & $\begin{array}{c}\text { Pseudomonas mesoacidophila } \\
\& \\
\text { Pseudomonas acidophila }\end{array}$ & 22 \\
\hline Bulgecin A & $1 \mathrm{~g}^{\mathrm{a}}$ & Pseudomonas mesoacidophila & 23 \\
\hline Bulgecin B & $1 h^{a}$ & Pseudomonas mesoacidophila & 23 \\
\hline Bulgecin C & $1 \mathrm{i}^{\mathrm{a}}$ & Pseudomonas mesoacidophila & 23 \\
\hline Pterocidin & $1 \mathbf{j}^{\mathrm{a}}$ & Streptomyces hygroscopicus & 10 \\
\hline Methoxyneihumicin & $1 k^{a}$ & $\begin{array}{c}\text { Nocardiopsis alba SCSIO } \\
03039\end{array}$ & 13 \\
\hline Nocazine D & $11^{\mathrm{a}}$ & $\begin{array}{c}\text { Nocardiopsis alba SCSIO } \\
03039\end{array}$ & 13 \\
\hline Nocazine E & $1 \mathrm{~m}^{\mathrm{a}}$ & $\begin{array}{c}\text { Nocardiopsis alba SCSIO } \\
03039 \\
\end{array}$ & 13 \\
\hline 3 & $1 n^{a}$ & $\begin{array}{c}\text { Nocardiopsis alba SCSIO } \\
03039\end{array}$ & 13 \\
\hline 4 & $10^{a}$ & $\begin{array}{c}\text { Nocardiopsis alba SCSIO } \\
03039\end{array}$ & 13 \\
\hline 5 & $1 p^{a}$ & $\begin{array}{c}\text { Nocardiopsis alba SCSIO } \\
03039 \\
\end{array}$ & 13 \\
\hline XR334 & $2 a^{b}$ & $\begin{array}{c}\text { Nocardiopsis alba SCSIO } \\
03039\end{array}$ & 13 \\
\hline 7 & $2 \mathbf{b}^{b}$ & $\begin{array}{c}\text { Nocardiopsis alba SCSIO } \\
03039\end{array}$ & 13 \\
\hline 8 & $2 c^{b}$ & $\begin{array}{c}\text { Nocardiopsis alba SCSIO } \\
03039\end{array}$ & 13 \\
\hline Surfactin A & $2 d^{b}$ & Bacillus subtilis & 24 \\
\hline Surfactin B & $2 e^{b}$ & Bacillus subtilis & 24 \\
\hline Surfactin C & $2 f^{b}$ & Bacillus subtilis & 24 \\
\hline Surfactin D & $2 g^{b}$ & Bacillus subtilis & 24 \\
\hline Bacilysin & $3 a^{c}$ & $\begin{array}{c}\text { B. subtilis, } \\
\text { B. amyloliquefaciens, } \\
\text { B.pumilus } \\
\end{array}$ & 25,26 \\
\hline Bacilysocin & $3 \mathbf{b}^{\mathrm{c}}$ & Bacillus subtilis & 26,27 \\
\hline 3,3`-Neotrehalosadiamine(NTD) & $3 c^{c}$ & $\begin{array}{l}\text { B. subtilis, B. pumilus, } \\
\text { B. circulans }\end{array}$ & 26,28 \\
\hline
\end{tabular}


Indo Global Journal of Pharmaceutical Sciences, 2014; 4(2): 52-64

\begin{tabular}{|c|c|c|c|}
\hline Amicoumacin $\mathrm{A}$ & $3 d^{c}$ & B. subtilis, B. pumilus & 26,29 \\
\hline Amicoumacin B & $3 e^{c}$ & B. subtilis, B. pumilus & 26,29 \\
\hline Amicoumacin $\mathrm{C}$ & $3 f^{c}$ & B. subtilis, B. pumilus & 26,29 \\
\hline Macrolactin & $3 g^{c}$ & B. amyloliquefaciens & 26,30 \\
\hline$\beta$-Exotoxin & $3 h^{c}$ & B. thuringiensis & 26,31 \\
\hline Zwittermicin A & $3 \mathbf{i}^{\mathrm{c}}$ & $\begin{array}{c}\text { B. thuringiensis, } \\
\text { B. cereus }\end{array}$ & 26,32 \\
\hline Petrobactin & $3 \mathbf{j}^{\mathrm{c}}$ & $\begin{array}{c}\text { B. thuringiensis, } \\
\text { B. cereus, } \\
\text { B. anthracis }\end{array}$ & 26,33 \\
\hline Bacircine & $4 a^{d}$ & $\begin{array}{c}\text { B. subtilis, } \\
\text { B. amyloliquefaciens, } \\
\text { B.pumilus }\end{array}$ & 26,34 \\
\hline Halobacillin & $4 b^{d}$ & B. licheniformis & 26,34 \\
\hline Lichenysin & $4 c^{d}$ & B. licheniformis & 26,35 \\
\hline Difficidin & $4 d^{d}$ & B. amyloliquefaciens & 26,36 \\
\hline Oxydifficidin & $4 e^{d}$ & B. amyloliquefaciens & 26,36 \\
\hline
\end{tabular}

\section{a, b, c \& d refer to Figure 1(I), Figure 1(II), Figure 1(III) \& Figure 1(IV) respectively.}

Using ChemDraw Ultra (CambridgeSoft Corporation, MA02140, USA), their structures were re-drawn and presented in Figure 1(I) to Figure 1(IV). The traditional paradigm of thought in this field was revolutionized by a range of discoveries showing presence structural elements known to occur only in eucaryotes. Several metabolites isolated from bacteria were found to possess diverse motif like pyrrolo[1,2-a]pyrazine, indole, $\beta$-lactam, pyrolidine, pyran, tetrahydropyrazine, diketopiperazine, 7-oxabicyclo[4,10]heptanes, isocoumarin, purine, naphthoquinone etc. Perusal of these structures revealed the presence of structural motifs and scaffolds, which are known to be present in various plants and fungal secondary metabolites. For example, the $\beta$-lactam motif has been known to occur in fungal metabolites. However, Imada and coworkers reported its presence in bacterial metabolites- sulfazecin and isosulfazecin, isolated from Pseudomonas mesoacidophila and $P$. acidophila [22]. Likewise, indole alkaloids were primarily meant to be from plant source, yet Martinez-Luis and coworkers were able to isolate them from Bacillus pumilus in 2012 [17].

Table 2. Structural classification of bacterial metabolites.

\begin{tabular}{|c|c|c|}
\hline S.No & Structural Class & Bacterial Metabolites \\
\hline 1 & $\beta$-lactam Antibiotics & $\begin{array}{ll}- & \text { Sulfazecin } \\
\text { - } & \text { Isosulfazecin }\end{array}$ \\
\hline 3 & Bacteriocin & $\begin{array}{ll}- & \text { Thuricin } \\
- & \text { Kurstakin } \\
- & \text { Entomocin } \\
- & \text { Lichenin } \\
- & \text { Megacin } \\
- & \text { Bacthuricin } \\
- & \text { Tochicin } \\
- & \text { Coagulin } \\
- & \text { Cerein } \\
- & \text { Polyfermenticin }\end{array}$ \\
\hline $\mathrm{C}$ & Cyclic Lipoheptapeptide & $\begin{array}{ll}\text { - } & \text { Surfactin A-D } \\
\text { - } & \text { Bacillomycin } \\
\text { - } & \text { Iturin } \\
\text { - } & \text { Bacircine } \\
\text { - } & \text { Halobacillin } \\
\text { - } & \text { Isohalobacillin } \\
\text { - } & \text { Fengycin } \\
\text { - } & \text { Mycosubtilin } \\
\text { - } & \text { Lichenysin } \\
\text { - } & \text { Pumalacidin } \\
\text { - } & \text { Daitocidin }\end{array}$ \\
\hline
\end{tabular}




\section{Indo Global Journal of Pharmaceutical Sciences, 2014; 4(2): 52-64}

\begin{tabular}{|c|c|c|}
\hline 4 & Catecholate Siderophore & $\begin{array}{ll}- & \text { Bacillibactin } \\
- & \text { Petrobactin } \\
- & \text { 3,4-dihyroxybenzoic } \\
& \text { acid }(3,4-\text { DHB })\end{array}$ \\
\hline 5 & Diketopiperazine & $\begin{array}{ll}- & \text { Nocazine D } \\
- & \text { Nocazine E } \\
- & \text { XR334 }\end{array}$ \\
\hline 6 & Indole Alkaloids & $\begin{array}{ll}- & \text { 3-Hydroxyacetylindole } \\
- & N \text {-acetyl- } \beta \text { - } \\
& \text { oxotryptamine } \\
- & \text { 3-Formylindole }\end{array}$ \\
\hline 7 & Lantibiotic & $\begin{array}{ll}- & \text { Sublancin } \\
- & \text { Subtilin } \\
- & \text { Ericin } \\
- & \text { Subtilolysin } \\
- & \text { Mersacidin }\end{array}$ \\
\hline 8 & Polyketide Macrolactone & $\begin{array}{ll}- & \text { Difficidin } \\
- & \text { Bacillaene } \\
- & \text { Macrolactin }\end{array}$ \\
\hline 9 & Aminopolyol & - Zwittermicin \\
\hline 10 & Isocoumarin & $\begin{array}{ll}- & \text { Amicoumacin A } \\
- & \text { Amicoumacin B } \\
- & \text { Amicoumacin C }\end{array}$ \\
\hline 11 & Amino Sugar & $\begin{array}{l}\text { - } 3,3{ }^{\prime}- \\
\text { Neotrehalosadiamine(NT } \\
\text { D) }\end{array}$ \\
\hline 12 & Adenine Nucleotide & $-\quad \beta$-Exotoxin \\
\hline 13 & Polyacetilene Analog & - $\quad$ Melanin \\
\hline 14 & Dipeptide & - $\quad$ Bacilysin \\
\hline 15 & Phospholipid & - $\quad$ Bacilysocin \\
\hline 16 & $\begin{array}{c}\text { Prenylated } \\
\text { Naphthoquinones }\end{array}$ & $\begin{array}{ll}- & \text { Fumaquinone } \\
- & \text { Naphterpin } \\
- & \text { Naphthgeranines } \\
- & \text { Napyradiomycin } \\
- & \text { Furaquinocins } \\
- & \text { Marinone } \\
- & \text { Neomarinone } \\
\end{array}$ \\
\hline 17 & $\begin{array}{l}\text { Synthetic Analogues of } \\
\text { Cyclic Lipoheptapeptide }\end{array}$ & $\begin{array}{ll}- & \text { Azasurfactin } \\
- & \text { 3-Epi-Azasurfactin } \\
- & \text { SSL14 } \\
- & \text { SAL14 } \\
- & \text { SSL10 } \\
- & \text { SSL18 }\end{array}$ \\
\hline
\end{tabular}

Interestingly, the secondary metabolites from eukaryotic sources have been shown to possess therapeutic properties. For example, vitamin $K_{1} \& K_{2}$ are derivatives of 1,4naphthoquinone, henceforth secondary metabolite 7 (refer structure 2b in Figure 1(II)) of Nocardiopsis alba SCSIO 03039 could be the possible bioisoster/analog to Vitamin $K_{1}$ \& $\mathrm{K}_{2}$. Similarly, well known anticancer drugs like azathioprine and mercaptopurine belongs to the chemical class of purine analogues which is exclusively shared by $\beta$ exotoxin, metabolite of $B$. thuringiensis(refer structure $\mathbf{3 h}$ in Figure 1(III)). Skatole, phytoconstituent of jasmine and primary composition of jasmine oil is having the same indole ring as possessed by some of the bacterial metabolites (refer structure 1b, 1c \& 1e in Figure 1(I)). The presence of such structural elements in bacterial metabolites is a strong indication of their functionally diverse nature. However, extensive research needs to be undertaken to establish the structure-function relationships for metabolites of bacterial origin.

Structural classification of the bacterial metabolites may prove to be handy for further studies on their structure and function. Accordingly, we have attempted to frame the classification of bacterial metabolites. Based on the analysis, the bacterial metabolites could be assigned to 17 different structural classes (Table 2). 
<smiles>CC(C)C[C@@H]1NC(=O)[C@@H]2CCCN2C1=O</smiles>

1a<smiles>O=Cc1c[nH]c2ccccc12</smiles>

1e

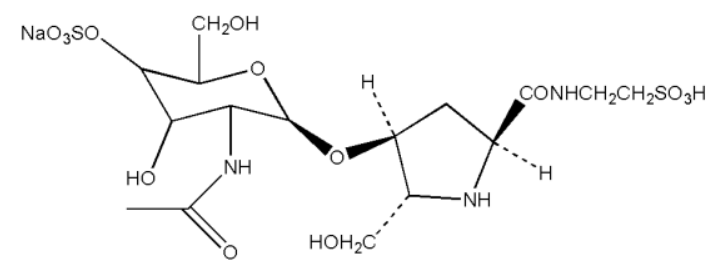

$1 \mathrm{~g}$

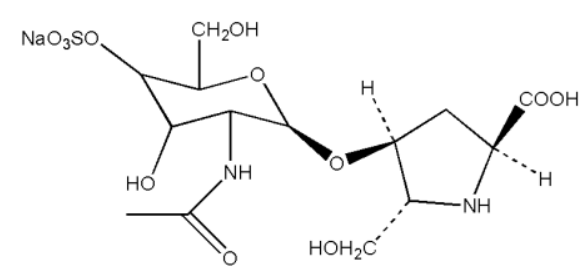

$1 \mathrm{i}$<smiles>O=C(CO)c1c[nH]c2ccccc12</smiles>

$1 \mathbf{b}$<smiles>CC(=O)NCC(=O)c1c[nH]c2ccccc12</smiles><smiles>O=C1N[C@H](Cc2ccccc2)C(=O)N2CCC[C@H]12</smiles>

1d<smiles>CO[C@@]1(N[C@@H](C)C(=O)NC(=O)CC[C@H](N)C(=O)O)CN(S(=O)(=O)O)C1=O</smiles><smiles>CC(=O)NC1C(O)C([R6]([O-])([O-])O[Na])C(CO)O[C@H]1O[C@H]1C[C@H](C(=O)OCC(=O)O)N[C@H]1CO</smiles>

1h<smiles>CC/C=C/C=C(\OC)C(O)C(C)CC(/C=C/C=C/C1OC(C)=CCC1OC)OC</smiles>

$1 \mathbf{j}$<smiles>COc1ccc(/C=c2\nc(OC)/c(=C/c3ccccc3)[nH]c2=O)cc1</smiles>

$1 \mathbf{k}$<smiles>COc1ccc(/C=C2\NC(=O)C(Cc3ccccc3)NC2=O)cc1</smiles><smiles>C[C@H]1NC(=O)/C(=C/c2ccccc2)NC1=O</smiles><smiles>CC(C)[C@H]1NC(=O)/C(=C/c2ccccc2)NC1=O</smiles><smiles>COc1ccc(/C=c2\[nH]c(=O)/c(=C/C(C)C)[nH]c2=O)cc1</smiles>

Figure 1(I): Chemical structures of bacterial metabolites. Necessary data were obtained from the relevant references as cited in Table 1. In view of large volume of structures, they are presented in four parts: I-IV. 1a: Cyclo-(L-Leu- $L$-Pro); 1b: 3hydroxyacetylindole; 1c: $N$-acetyl- $\beta$-oxotryptamine; 1d: cyclo-(L-Phe-L-Pro; 1e: 3-formylindole; 1f: Sulfazecin; 1g: Bulgecin A; 1h: Bulgecin B; 1i: Bulgecin C; 1j: Pterocidin; 1k: Methoxyneihumicin; 1l: Nocazine D; 1m: Nocazine E; 1n: 3; 1o: 4; 1p: 5. 


\section{Indo Global Journal of Pharmaceutical Sciences, 2014; 4(2): 52-64}<smiles>COc1ccc(/C=c2\[nH]c(=O)/c(=C/c3ccccc3)[nH]c2=O)cc1</smiles><smiles>COC1=CC(=O)c2ccccc2C1=O</smiles><smiles>COc1cc(C(=O)O)c(O)c2ccccc12</smiles>
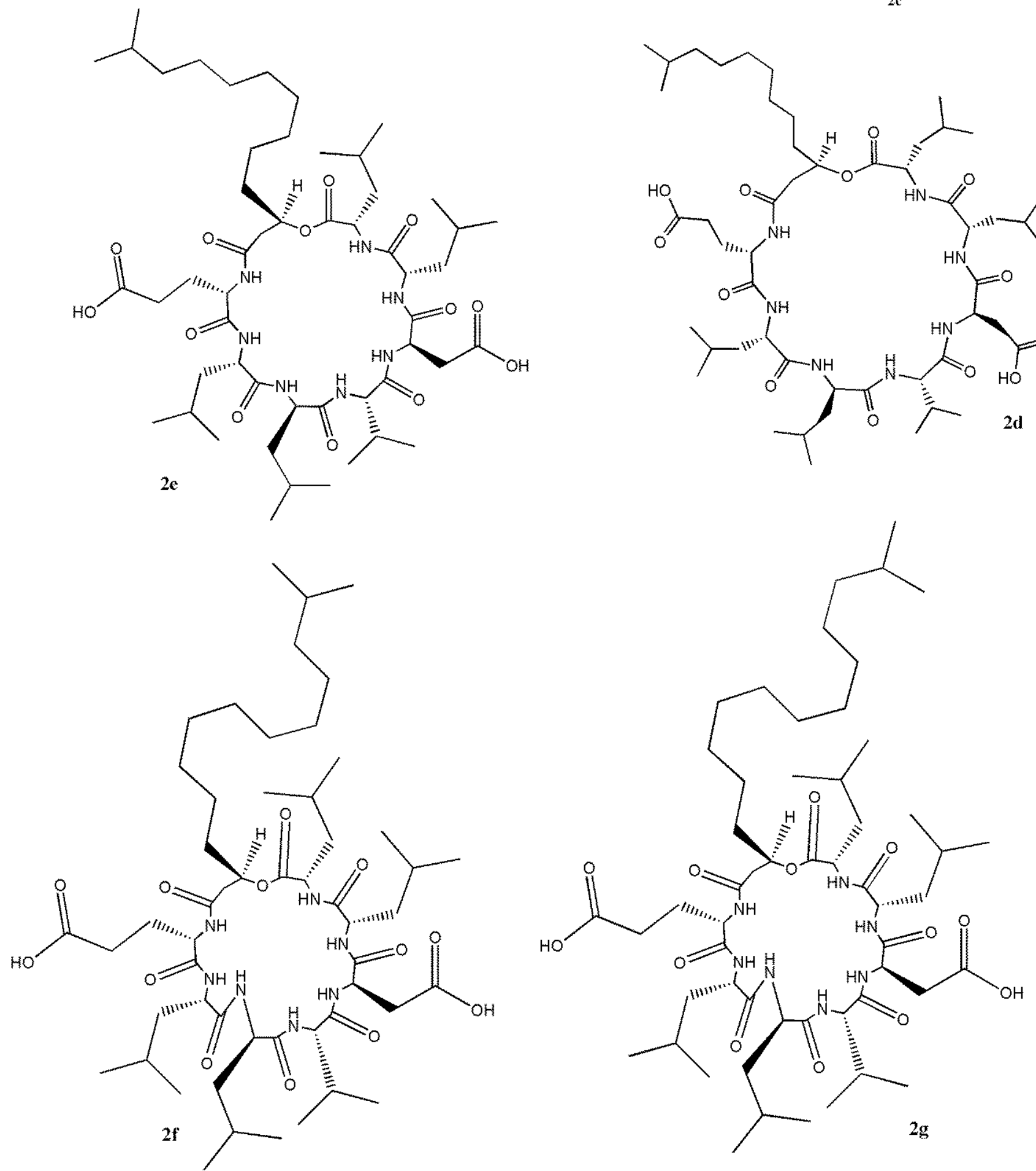

Figure 1(II): 2a: XR334; 2b: 7; 2c: 8; 2d: Surfactin A; 2e: Surfactin B; 2f: Surfactin C; 2g: Surfactin D. 
Indo Global Journal of Pharmaceutical Sciences, 2014; 4(2): 52-64<smiles>CC(N)C(=O)NC(CC1CCC(=O)C2OC12)C(=O)O</smiles><smiles>CCC(C)CCCCCCCCCCC(=O)OCC(O)COP(=O)([O-])OCC(O)CO</smiles><smiles>NC1C(O)C(CO)OC(OC2OC(CO)C(O)C(N)C2O)C1O</smiles><smiles>CC(C)CC(NC(=O)C(O)C(O)C(N)CC(N)=O)C1Cc2cccc(O)c2C(=O)O1</smiles><smiles>CC(C)CC(NC(=O)C(O)C(O)C(N)CC(=O)O)C1Cc2cccc(O)c2C(=O)O1</smiles><smiles>CC(C)CC(NC(=O)C(O)C(O)C1COC1=O)C1Cc2cccc(O)c2C(=O)O1</smiles><smiles>CCCCC/C=C\CC(O)/C=C/C=C\CC(O)CC(O)/C=C/C=C/C=C\C1CC1</smiles><smiles>CC(C)OC(=O)OC(=O)C(O)C(O)C(O[C@H]1O[C@H](CO)[C@@H](OC[C@H]2O[C@@H](n3cnc4c(N)ncnc43)[C@H](O)[C@@H]2O)[C@H](O)[C@@H]1O)C(=O)O</smiles><smiles>NC(=O)NC[C@H](NC(=O)[C@@H](O)[C@H](O)[C@H](N)[C@H](O)C[C@H](O)[C@H](N)CO)C(N)=O</smiles>

Figure 1(III): 3a: Bacilysin; 3b: Bacilysocin; 3c: 3,3 -Neotrehalosadiamine(NTD); 3d: Amicoumacin A; 3e: Amicoumacin B; 3f: Amicoumacin C; 3g: Macrolactin; 3h: $\beta$-Exotoxin; 3i: Zwittermicin A; 3j: Petrobactin. 
Indo Global Journal of Pharmaceutical Sciences, 2014; 4(2): 52-64

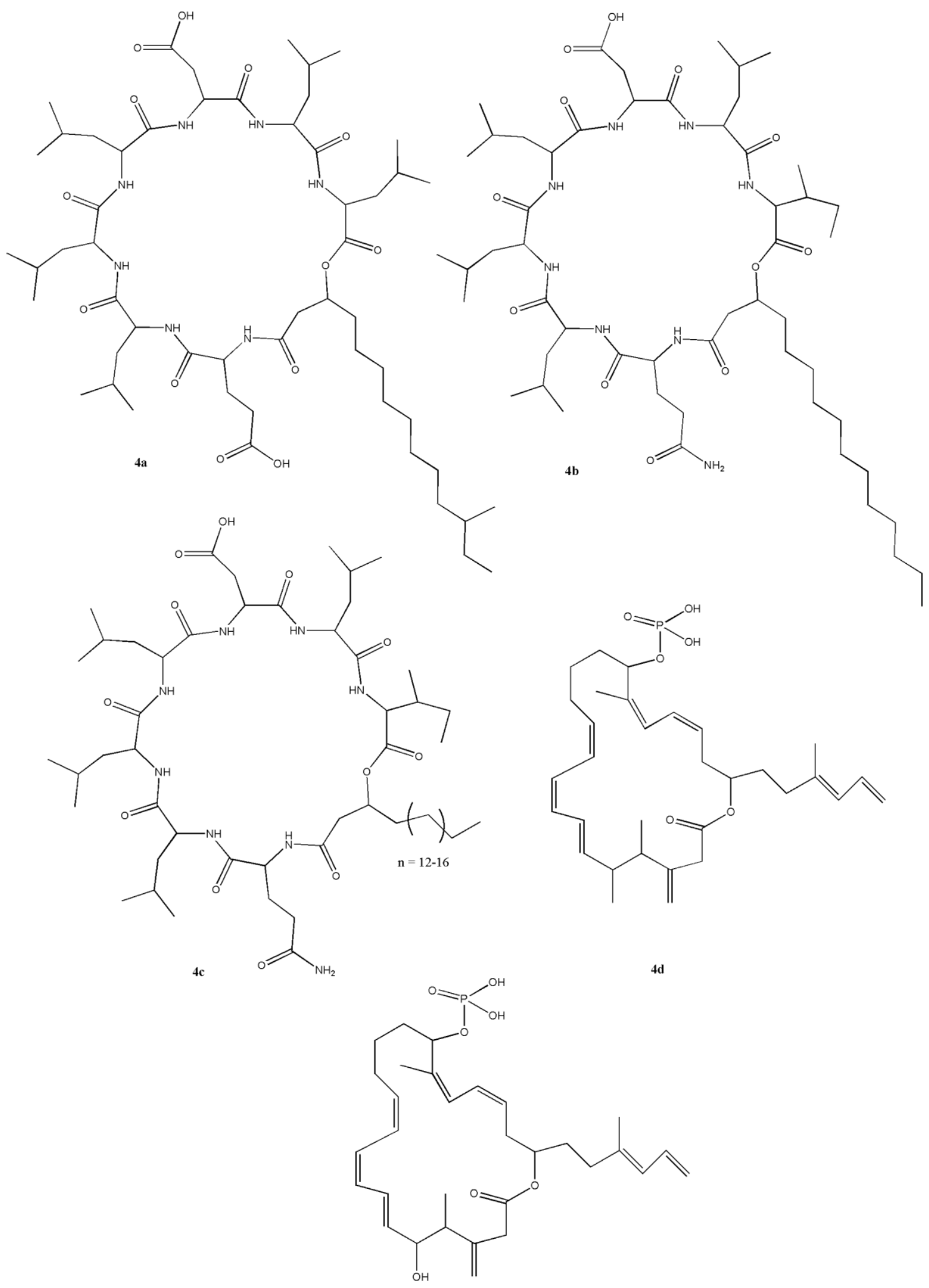

Figure 1(IV): 4a: Bacircine; 4b: Halobacillin; 4c: Lichenysin; 4d: Difficidin; 4e: Oxydifficidin. 


\section{THERAPEUTIC SPECTRUM OF THE BACTERIAL METABOLITES}

\begin{abstract}
Anti-diabetic Adjuvant
The nasal administration of insulin preparation to rats resulted in dose dependent hypoglycaemia. The bioavailability of insulin via nasal route is enhanced in the presence of surfactants [4]. Okumura and coworkers had identified the supporting role of surfactin to improve the bioavailability of insulin when taken by the intratracheal route in male wistar rats. At a concentration level of $\quad 3.0 \mathrm{U} / \mathrm{kg}$, intratracheally administered insulin had bioavailability of only $13.1 \%$. But in the presence of $10 \mathrm{mM}$ surfactin, the bioavailability was raised to $80 \%$. This certainly reflects the synergistic role of surfactin in increasing insulin bioavailability when administered through nasal route [5].
\end{abstract}

\section{Antiulcer Activity}

Pumilacidin B, a metabolite of B. pumilus was found to have an inhibitory effect on $\mathrm{H}^{+}, \mathrm{K}^{+}$- ATPase when compared with four known acylpeptide antibiotics and two known $\mathrm{H}+, \mathrm{K}+$-ATPase inhibitors, omeprazole and SCH28080. It also displayed antiulcer activity in male wistar rats [14]. In light of the potential side effect profile of the currently used proton pump inhibitors (PPI), the more serious of which include: headaches, gastrointestinal disturbances, rash and various serious medication interactions including with methotrexate [37,38]; this alternative potential PPI agent may be of significant therapeutic benefit to certain patient groups.

New antibiotics pumalicidins A, B, C, D, E, F \& G were isolated from the culture broth of a strain of Bacillus pumilus. The test compound was given subcutaneously in a volume of $0.1 \mathrm{ml} / 100 \mathrm{~g}$ body weight soon after pyrolysis ligation. Shay ulcers were significantly inhibited (68\%) when $100 \mathrm{mg} / \mathrm{kg}$ of pumalacidin B was administered [14].

\section{Anti-inflammatory Activity}

Tang and coworkers have demonstrated anti-inflammatory activity of surfactin isomers, which were isolated from mangrove bacterium Bacillus sp. Inhibitory activity of surfactin isomers on the overproduction of nitric oxide (NO) and the release of TNF- $\alpha$ as well as IL-6 in LPS induced murine macrophages RAW264.7 was identified. Surfactin isomers exhibited significant control on the overproduction of NO, release of TNF- $\alpha$ and IL-6 with an IC50 value of 1.0-5.0 $\mu \mathrm{M}, 1.0-7.0 \mu \mathrm{M}$ and 10-30 $\mu \mathrm{M}$ respectively. Structure activity relationship (SAR) studies revealed the importance of free carboxyl group, since monomethylated derivatization of surfactin isomers decreased the inhibitory effect on overproduction of nitric oxide, release of IL- 6 and TNF- $\alpha$ while tested in LPS induced murine macrophages RAW264.7, in totality loss of anti-inflammatory activity [8]. Moreover, surfactin exhibited in vivo anti-inflammatory activity in several tested inflammatory reactions including TPA induced mouse ear edema, carrageenan-induced rat paw edema and acetic acid induced mouse writhing. Surfactin blocked non-stimulated and calcium ionophore A23187-stimulated release of arachidonic acid from monkey kidney CV-1 cells, which contain a cytosolic $100 \mathrm{kDa}$ tical Sciences, 2014; 4(2): 52-64

PLA2 as the major activity. These results suggested that surfactin along with inhibition of NO overproduction and release of TNF- $\alpha$ and IL-6, is a selective inhibitor for cytosolic PLA $\mathrm{P}_{2}$ and putative anti-inflammatory agent ${ }^{7}$. The current use of anti TNF- $\alpha$ agents are a cornerstone in the treatment an extensive range of rheumatological conditions. However their cost and side effect profile [39] often limits their use. Therefore to have an alternative mode of TNF alpha blockage will be a tremendous therapeutic advantage.

\section{Antioxidant and DNA Protective Effects}

Reactive oxygen species and free radicals like superoxide anions, hydrogen peroxide and hydroxyl radicals have been shown to cause cell death and tissue damage. Because of the toxic sources of synthetic antioxidants, significant interest is now being shown in natural antioxidants and a number of investigations have already been carried out to explore medicinal flora. Bacillomycin D homologues isolated from Bacillus subtillis B38 were found to exhibit strong reducing power activity, hydroxyl and superoxide anion radicals scavenging activities and inhibition of lipid peroxidation. Furthermore, they also demonstrated an anticlastogenic effect to protect plasmid DNA against damage from hydroxyl radical oxidation. Their antioxidant potency can be attributed to the hydrophobic and aromatic side-chain groups as well as aliphatic chain, however it doesn't seem to be affected by the hydrocarbon chain length. So because of their high stability in relation to temperature and their resistance to proteases, these compounds could be useful ingredients for within the cosmetic and pharmaceutical industry [6, 40-41].

\section{Apoptotic Activity}

Induction of apoptosis, a major way of programmed cell death, is an established but also constantly evolving strategy in cancer treatment. According to the MTT assay, Surfactin - cyclic lipopeptide metabolite of Bacillus subtilis CYS191, inhibited the growth of MCF-7 human breast cancer cells in a dose dependent manner, with an IC50 value of approx $10 \mu \mathrm{g} / \mathrm{ml}$, via ROS/JNKmediated mitrochondrial/caspase pathway induced apoptosis [1112]. Additionally, Streptomyces hygroscopicus TA-AO451 produced pterocidin exhibited cytotoxicity against some human cancer cell lines NCI-H522, OVCAR-3, SF539 and LOX-IMVI with IC50 values of 2.9, 3.9, 5.0, and $7.1 \mu \mathrm{M}$ respectively [10]. Bonard and Co-workers investigated the cytotoxic activities of laxaphycin A \& B (Cyclic lipopeptides from marine cyanobacterium Lyngbya majuscula) against drug sensitive and multidrug resistant human tumor cell lines like CCRF-CEM, CEM/VLB100, CEM/VM-1, and data revealed that laxaphycin A

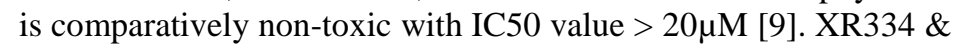
methoxyneihumicin, diketopiperazine produced by Nocardiopsis alba SCSIO 03039, exhibited invitro cytotoxicities against MCF-7 and SF-268 with IC50 values at 22.0, 20.6 $\mu \mathrm{M}$ and 4.6, $12.7 \mu \mathrm{M}$ respectively [13].

\section{Autoimmune Disease}

Park and Kim investigated and demonstrated the effect of surfactin on antigen-presenting property of macrophages. Peritoneal macrophages of thioglycollate-elicited mouse were evaluated for surface molecule expression, phagocytosis, cytokine production, capacity to induce T-cell activation, and underlying signaling 


\section{Indo Global Journal of Pharmaceutical Sciences, 2014; 4(2): 52-64}

pathways. Interestingly, this lipopeptide suppressed LPS induced expression of CD40, CD54, CD80, MHC-II and impaired phagocytosis in treated macrophages as well as reduced IL-2 expression. Surfactin markedly inhibited the activation of CD4+ T cells. Impaired translocation and activation of NF- $\mathrm{KB}$ p 65 were found on macrophages exposed to surfactin. In addition, surfactin inhibited the phosphorylation and degradation of IкB- $\alpha$, and suppressed the activation of IKK, Akt, JNK and p38 kinase. These results suggest that surfactin impair the antigen-presenting function of macrophages by inhibiting the expression of MHC-II and other costimulatory molecules via suppression of NF- $\kappa B, p 38$, JNK and Akt. Hence, surfactin and its analogs may potentially be used as treatment in autoimmune disease and transplantation because of its immunopharmacological role [15].

\section{Immunostimulatory Activity}

Bacillus amyloliquefaciens WH1 produces a novel immunoadjuvant type surfactin cyclopeptide, WH1fungin. It markedly enhances the immune response when given in mixture with antigens. Both IgG1 and IgG2a antigen-specific antibodies were elicited from the immunizations indicating a mixed Th1/Th2 response. WH1fungin helps to elicit humoral and cellular responses to OVA. Apart from this, Gao and Coworkers reported that WH1fungin can enter in the RAW 264.7 cells that leads to the ROS accumulation, upregulation of cell surface markers and cytokines in cells. Moreover, WH1fungin have a tendency to exert its adjuvant nature by ligating itself with TLR-2 in antigen comprising cells like RAW 264.7. So, in summary, WH1fungin has the potential to be used as a suitable adjuvant during vaccine development [16].

\section{Hemolytic Activity}

Surfactin and its cyclic lipopeptide analogs exhibit hemolytic activity which is indeed a drawback for medical applications. To overcome the problem, Dufour and coworkers had synthesized linear analogs of surfactin. In contrast to cyclic surfactins, linear analogs elicit negligible hemolytic activity while retaining the surface active characteristics [42]. Keeping these facts in mind, Sulfazecin, isosulfazecin, pterocidin and other bacterial metabolites similar to linear surfactin derivatives are less likely to have hemolytic property.

\section{Fibrinolytic Activity}

As suggested by Sherry and coworkers, the plasminogen/plasmin system is activated in a wide variety of circumstances in addition to its recognized physiological role. Amongst others, these include: wet cupping, adrenaline injections, emotions, exercise and medical/operative procedures [43]. Zymogen plasminogen is proteolytically activated by urokinase-type plasminogen activator (UPA) and tissue type plasminogen activator (TPA). Kikuchi and Hasumi found that surfactin C (lipopeptidal metabolite of bacillus $s p$. A9184) in a concentration range of 3-20 $\mu \mathrm{M}$, enhances the activation of pro-UPA in the presence of plasminogen. Surfactin C also elevated the rate of plasminogen activation by two chain urokinase(tcu-PA) while not affecting plasmin catalyzed pro-UPA and amidolytic activities of tcu-PA and plasmin. Rat pulmonary embolism model assessment suggested that surfactin $\mathrm{C}$ in combination with pro-UPA elevated ${ }^{125}$ I plasma clot lysis at an intravenous dose of $1 \mathrm{mg} / \mathrm{kg}$ [44].

\section{Antiviral Activity}

Kracht and coworkers demonstrated the antiviral properties of surfactin isoforms (non-ribosomal products of Bacillus subtilis against vesicular stomatitis virus (VSV, rhabdoviridae), suid herpes virus type 1 (SHV-1, herpesviridae, model virus for human herpes virus) and semliki forest virus (SFV, togaviridae, model virus for hepatitis $\mathrm{C}$ virus). The length of the carbon chain in cyclic lipopeptide surfactin seems to be an influencing factor in its capacity for viral inactivation. Semi-synthetic products in the form of methyl esters were also taken into consideration. A monomethyl ester of C15 surfactin inactivated SFV, which was resistant to the mixture of surfactin isoforms. On the contrary, its dimethylated form was inactive, revealing the necessity of one negative charge on the peptide along with fatty acid chain length of 15 for their inactivation capacity [45]. Bacillus subtilis fmbj (CGMCC No. 0934) can produce antimicrobial lipopeptides (AMLs) like surfactin and fengycin. These AMLs have been found to have antiviral activity against pseudorabies virus (PRV), porcine parvovirus (PPV), newcastle disease virus (NDV) and infectious bursal disease virus (IBDV) when evaluated in vitro. These AMLs represented a direct inactivation effect on cell-free virus stocks of PRV, PPV, NDV and IBDV. They were found to effectively inhibit infection and replication of the NDV and IBDV, however, failed to affect PRV and PPV. The Selectivity Index of AMLs on PRV, PPV, NDV and IBDV was 1.44, 2.23, 8.40 and 12.19 respectively [46].

Acyclovir is currently the most commonly used antiviral agent against the human herpes virus, despite the fact that its effectiveness in reducing pain from lesions is quite limited [47]. Similarly, Interferons are a significant aspect of Hepatitis C management; however, they carry a range of commonly experienced and debilitating side effects [48-51]. Therefore, further research into this attribute of bacterial metabolites appears quite promising.

\section{Treatment of Septic Shock}

Cell wall of gram negative bacteria composed majorly of lipopolysaccharide (LPS), which can lead to the septic shock and endotoxemia [52] and consequently have devastating effects on the cardiopulmonary systems (amongst others). Adequate treatment of patients with unexplained shock requires thorough evaluation of its etiology and assessment of cardiac function [53]. Polypeptide antibiotics like polymyxins are being used clinically for treatment of shock, but their toxicity/side effects can't be ignored, thus, reducing their clinical utility. Surfactin C, an isomer of general surfactin, had been used in experiments on male ICR mice and Sprague-dawley rat models of gram negative septic shock, to evaluate its anti-endotoxin activity. Surfactin C not only completely bound to LPS, but also reduced the plasma endotoxin, tumor necrosis factor- $\alpha$ and nitric oxide levels in response to septic shock in rats [52]. As discussed above, cyclic surfactins induced hemolysis, henceforth their linear analogs can be prospective adjuvant in the management of septic shock, with a far more favorable side effect profile. 


\section{Indo Global Journal of Pharmaceutical Sciences, 2014; 4(2): 52-64}

\section{Treatment of Periodontitis}

Park and Coworkers observed the role of surfactin in the treatment of periodontal disease caused by Porphyromonas gingivalis. Surfactin inhibits inflammation caused by $P$. gingivalis by blocking activation of $P$. gingivalis LPS-triggered nuclear factorkappa $\mathrm{B}$, and also induces heme oxygenase- 1 mRNA \& protein expression via activation of $\mathrm{NrF}-2$. Furthermore, inhibition of PI3K/AkT \& ERK significantly decreases surfactin induced HO-1 expression. So in summary, Surfactin appears to be a potential candidate in strategies to prevent caries, periodontitis or other inflammatory diseases [54].

\section{Antitrypanosomal Activity}

American trypanosomiasis, also referred as Chagas disease, contributes heavily to the burden of disease within Latin America and African countries. However, there is a considerable lack of research regarding it by pharmaceutical companies and research institutes. Unfortunately, the current therapeutic methods for treatment of American trypanosomiasis have considerable side effects and consequently there is very poor patient compliance. Three alkaloids [3-hydroxyacetylindole; $\mathrm{N}$-acetyl- $\beta$-oxotryptamine and 3-formylindole) out of the five isolated from marine Bacillus pumilus exhibited potential antitrypanosomal activity against $T$. cruzi, with $\mathrm{IC}_{50}$ in a range of 19.4 to $26.9 \mu \mathrm{M}$. In contrast the standard nifurtimox has an $\mathrm{IC}_{50}$ of $1.6 \mu \mathrm{M}$. This generates an impetus for the study of these marine alkaloids, and the exploration of other metabolites of microorganisms for the effective design of agents to combat $T$. cruzi [17].

\section{Mosquito Pupicidal Activity}

Interruption of transmission of mosquito borne diseases is the primary aim of vector control strategies. Preliminary studies suggested some mosquitocidal bacterial agents like $B$. thuringenesis var. israelensis, B. sphaericus, B. alvei, B. brevis, $B$. circulans, Brevibacillus laterosporus, B. subtilis [55-63]. However, the full extent and nature of their toxins and their biocontrol potential is still unexplored.

Isoforms of surfactin, ranging from $\mathrm{C} 13-\mathrm{C} 15$, metabolites of Bacillus subtilis subsp. Subtilis (from mangrove forests of Andaman \& Nicobar Islands, India) were evaluated by Geetha and coworkers for their potential to kill larval and pupal stages of mosquitoes [64].

\section{CONCLUSION}

As bacteria often produce secondary metabolites in adverse and stressful circumstances, it may be hypothesized that the compounds have a role to play in the survival of bacteria under such circumstances. This is particularly well reflected in a very recent study conducted by Achard and co-workers [65]. When reviewing the published literature on bacterial metabolites, it can be observed that the vast majority of research has remained limited to the antibiotic properties of these compounds, leaving a significant range of other potentially therapeutic characteristics unexplored.

Bioactive molecules produced by bacteria have the potential to exert therapeutic effects in a wide range of ailments, often in areas where current medical approaches may not provide an ideal standard of care. These results provide further impetus for the discovery and clinical development of their semisynthetic analogs.

Due to this potential for therapeutic diversity, it may be concluded that, like phytomolecules, bacterial metabolites can assume the role of a multifunctional scaffold. And this forms the basis for further meticulous exploration of microbial metabolites by pharmacologists and microbiologists.

\section{ACKNOWLEDGEMENT}

SERB-Young Scientist Fellowship granted to RKS by Science \& Engineering Research Board (DST), Government of India vide Project No. SR/FT/LS-149/2011, is duly acknowledged.

\section{REFERENCES}

1. Jesman C, Mludzik A, Cybulska M. History of antibiotics and sulphonamide discoveries. Pol Merkur Lekarski 2011; 30: 3202.

2. Milind GW, Tickoo R, Joq MM, Bhole BD. How many antibiotics are produced by genus Streptomyces. Arch Microbiol 2001; 176: 386-390.

3. Ron EZ, Rosenberg E. Natural roles of biosurfactants. Environ Microbiol 2001; 3: 229-236.

4. Hirai S, Yashiki T, Mina H. Effect of surfactants on the nasal absorption of insulin in rats. Int J Pharm 1981; 9: 165-172.

5. Okumura K, Iwakawa S, Yoshida T, Seki T, Komada F. Intratracheal delivery of insulin absorption from solution and aerosol by rat lung. Int J Pharm 1992; 88: 63-73.

6. Tabbene $\mathrm{O}$ et al. Anitoxidative and DNA protective effects of bacillomycin D-like lipopeptides produced by B-38 strain. Appl Biochem Biotechnol 2012; 168: 2245-2256.

7. Kim K et al. Suppression of inflammatory responses by surfactin, a selective inhibitor of platelet cytosolic phospholipase A. Biochem Pharmacol 1998; 55: 975-985.

8. Tang J-S et al. Characterization and online detection of surfactin isomers based on HPLC-MS ${ }^{\mathrm{n}}$ analyses and their inhibitory effects on the overproduction of nitric oxide and the release of TNF- $\alpha$ and IL-6 in LPS induced macrophages. Mar Drugs 2010; 8: 2605-2618.

9. Bonnard I, Rolland M, Francisco C, Banaigs B. Total structure and biological properties of laxaphycins A \& B, cyclic Lipopeptides from the marine cyanobacterium Lyngbya majuscule. Lett Pept Sci 1997; 4: 289-292.

10. Igarashi Y, Miura SS, Fujita T, Furamai T. Pterocidin, a cytotoxic compound from the endophytic streptomyces hygroscopicus. J Antibiot 2006; 59(3): 193-195.

11. Cao XH et al. Surfactin induced apoptosis in human breast cancer MCF-7 cells through a ROS/JNK-mediated mitochondrial/caspase pathway. Chem Biol Interact 2010; 183: 357-362.

12. Lee $\mathrm{JH}$ et al. The production of surfactin during the fermentation of cheonggukjang by potential probiotic Bacillus subtilis CYS191 and the resultant growth suppression of MCF-7 human breast cancer cells. Food Chem 2012; 131: 1347-1354.

13. Zhang $\mathrm{Q}$ et al. New diketopiperazine derivatives from a deep sea derived Nocardiopis alba SCSIO 03039. J Antibiot 2013; 66: 31-36.

14. Naruse N, Tenmyo O, Kobaru S, Kamei H, Miyaki T, Konishi M, Oki T. Pumilacidin, a complex of new antiviral antibiotics: Production, isolation, chemical properties, structure and biological activity. J Antibiot 1990; 43: 267-280. 


\section{Indo Global Journal of Pharmaceutical Sciences, 2014; 4(2): 52-64}

15. Park SY, Kim YH. Surfactin inhibits immunostimulatory function of macrophages through blocking NK- $\mathrm{BB}$, MAPK and Akt pathway. Int Immunopharmaol 2009; 9: 886-893.

16. Gao $\mathrm{Z}$ et al. A surfactin cyclopeptide of WH1fungin used as novel adjuvant for intramuscular and subcutaneous immunization in mice. Peptides 2012; 38: 163-171.

17. Martinez-Luis S, Gomez JF, Spadafora C, Guzman HM, Gutierrez M. Antitrypansomal alkaloids from the marine bacterium Bacillus pumilus. Molecules 2012; 17: 11146-11155.

18. Aggarwal B, Ali M, Singh V, Singla RK. Isolation \& characterization of phytoconstituents from the stems of Ichnocarpus frutescens. Chin J Nat Med 2010; 8: 0401-0404.

19. Bankar GR et al. Vasorelaxant and antihypertensive effect of Cocos nucifera Linn. endocarp on isolated rat thoracic aorta and DOCA salt-induced hypertensive rats. J Ethnopharmacol 2011; 134: 50-54.

20. Li J, Huang Y, Guan XL. Anti-hepatitis B virus constituents from the stem bark of Streblus asper. Phytochemistry 2012; 82: 100-109.

21. Singla RK. Mechanistic evidence to support the anti-hepatitis B virus activity of multifunctional scaffold \& conformationally restricted Magnolol. Natl Acad Sci Lett 2014; 37(1): 45-50.

22. Imada A, Kitano K, Kinataka K, Muroi M, Asai M. Sulfazecin and isosulfazecin, novel $\beta$-lactam antibiotics of bacterial origin. Nature 1981; 289: 590-1.

23. Shinagawa S, Maki M, Kintaka K, Imada A, Asai M. Isolation and characterization of bulgecins, new bacterial metabolites with bulge-inducing activity. J Antibiot 1985; 38(1): 17-23.

24. Shaligram NS, Singhal RS. Surfactin- a review on biosynthesis, fermentation, purification and applications. Food Technol Biotechnol 2010; 48(2): 119-134.

25. Chmara $\mathrm{H}$ et al. Epoxypeptides - a novel group of metabolic inhibitors in procaryotic and eukaryotic organisms. Drugs Exp Clin Res 1982; 8: 11-12.

26. Sansinenea E, Ortiz A. Secondary metabolites of soil Bacillus spp. Biotechnol Lett 2011; 33: 1523-1538.

27. Tamehiro $\mathrm{N}$ et al. Bacilysocin, a novel phospholipid antibiotic produced by Bacillus subtilis 168. Antimicrob Agents Chemother 2002; 46: 315-320.

28. Tsuno T, Ikeda C, Numata K, Tomita K, Konishi M, Kawaguchi H. 3, 3`-Neotrehalosadiamine (BMY-28251), a new aminosugar antibiotic. J Antibiot 1986; 39: 1001-1003.

29. Pinchuk IV, Bressollier P, Sorokulova IB, Verneuil B, Urdaci MC. Amicoumacin antibiotic production and genetic diversity of Bacillus subtilis strains isolated from different habitats. Res Microbiol 2002; 153: 269-276.

30. Jaruchoktaweechai CS, Suwanboriux K, Tanasupawatt S, Kittakoop P, Menasveta P. New macrolactins from a marine Bacillus sp. Sc026. J Nat Prod 2000; 63: 984-986.

31. Espinasse S, Gohar M, Lereclus D, Sanchis V. An ABC transporter from Bacillus thuringiensis is essential for Bexotoxin I production. J Bacteriol 2002; 184: 5848-5854.

32. Silo-Suh LA, Stabb EV, Raffel SJ, Handelsman J. Target range of zwittermicin A, an aminopolyol antibiotic from Bacillus cereus. Curr Microbiol 1998; 37: 6-11.

33. Zawadzka AM, Abergel RJ, Nichiporuk R, Andersen UN, Raymond KN. Siderophore-mediated iron acquisition system in Bacillus cereus: identification of receptors for anthrax virulenceassociated petrobactin. Biochemistry 2009; 48: 3645-3657.

34. Kalinovskaya $\mathrm{N}$ et al. Characterization of surfactin-like cyclic depsipeptides synthesized by Bacillus pumilus Ascidian Halocynthia aurantium. Mar Biotechnol (NY) 2002; 4: 179189.
35. Grangemard I, Wallach J, Maget-Dana R, Peypoux F. Lichenysin: a more efficient cation chelator than surfactin. Appl Biochem Biotechnol 2001; 90: 199-210.

36. Arguelles-Arias A et al. Bacillus amyloliquefaciens GA1 as a source of potent antibiotics and other secondary metabolites for biocontrol of plant pathogens. Microb Cell Fact 2000; 8: 63-74.

37. Yang YX, Metz DC. Safety of proton pump inhibitor exposure. Gastroenterology 2010; 139: 1115-27.

38. Sheen E, Triadafilopoulos G. Adverse effects of long-term proton pump inhibitor therapy. Dig Dis Sci 2011; 56: 931-50.

39. Bongartz Tet al. Anti-TNF antibody therapy in rheumatoid arthritis and the risk of serious infections and malignancies: systematic review and meta-analysis of rare harmful effects in randomized controlled trials. JAMA 2006; 295: 2275-85.

40. Jayalakshmi S, Mishra A, Mishra A, Singla RK, Ghosh AK. Invitro evaluation of antioxidant activity of five drugs of trinpanchmool. Pharmacologyonline 2011; 2: 1153-1159.

41. Singla RK, Jaiswal N, Bhat VG, Jagani H. Antioxidant and antimicrobial activities of cocos nucifera Linn. (Arecaceae) endocarp students. Indo Global J Pharm Sci 2011; 1(4): 354361.

42. Dufour $\mathrm{S}$ et al. Hemolytic activity of new linear surfactin analogs in relation to their physic-chemical properties. Biochim Biophys Acta 2005; 1726: 87-95.

43. Sherry S, Lindemeyer RI, Fletcher AP, Alkjaesig N. Studies on enhanced fibrinolytic activity in man. J Clin Invest 1959; 38(5): 810-822.

44. Kikuchi T, Hasumi K. Enhancement of plasminogen activation by surfactin $\mathrm{C}$ : augmentation of fibrinolysis in vitro $\&$ in vivo. Biochim Biophys Acta 2002; 1596: 234-245.

45. Kracht $\mathrm{M}$ et al. Antiviral and hemolytic activity of surfactin isoforms and their methyl ester derivatives. J Antibiot 1999; 52(7): 613-619.

46. Huang $\mathrm{X}$ et al. Antiviral activity of antimicrobial lipopeptide from Bacillus subtilis fmbj against pseudorabies virus, porcine parvovirus, newcastle disease virus and infectious bursal disease virus. Int J Peptide Res Therapeutics 2006; 12(4): 373-377.

47. Ducoulombier $\mathrm{H}$ et al. Herpetic stomatis-gingivitis in children controlled trial of acyclovir versus placebo. Ann Pediatr 1988; 35: 212-216.

48. Vial T, Descotes J. Clinical toxicity of the interferons. Drug Saf 1994; 10: 115-50.

49. Pardo M, Marriott E, Moliner MC, Quiroqa JA, Carreno $\mathrm{V}$. Risks and benefits of interferon- $\alpha$ in the treatment of hepatitis. Drug Saf 1995; 13: 304-16.

50. Kirkwood JM et al. Mechanisms and management of toxicities associated with high-dose interferon alfa- $2 b$ therapy. J Clin Oncol 2002; 20: 3703-18.

51. Sleijfer S, Bannik M, Van Gool AR, Kruit WH, Stoter G. Side effects of interferon-alpha therapy. Pharm World Sci 2005; 27: 423-31.

52. Hwang YH et al. Lipopolysaccharide-binding and neutrazlizing activities of surfactin $\mathrm{C}$ in experimental models of septic shock. Eur J Pharmacol 2007; 556: 166-171.

53. Krivec B et al. Diagnosis and treatment of shock due to massive pulmonary embolism. Chest 1997; 112: 1310-16.

54. Park SY, Kim YH, Kim EK, Ryu EY, Lee SJ. Heme oxygenase1 signals are involved in preferential inhibition of proinflammatory cytokine release by surfactin in cells activated with Porphyromonas gingivalis lipopolysaccharide. Chem Biol Interact 2010; 188: 437-445.

55. Balaraman K, Bheema RUS, Rajagopalan PK. Bacterial pathogens of mosquito larvae-Bacillus alvei (Cheshire and Cheyene) and Bacillus brevis (Migula)-isolated in Pondicherry. Indian J Med Res 1979; 70: 615-619. 


\section{Indo Global Journal of Pharmaceutical Sciences, 2014; 4(2): 52-64}

56. Balaraman K, Balasubramanian M, Jambulingam P. Field trial of Bacillus thuringiensis $\mathrm{H}-14$ (VCRC B-17) against Culex and Anopheles larvae. Indian J Med Res 1983; 77: 38-43.

57. Balaraman K, Gunasekaran K, Pillai PK, Manonmani AM. Field trial with different formulations of Bacillus sphaericus for mosquito control. Indian J Med Res 1987; 85: 620-625.

58. Armengol G, Hernandez J, Velez JG, Orduz S. Long-lasting effects of a Bacillus thuringiensis serovar israelensis experimental tablet formulation for Aedes aegypti (Diptera: Culicidae) control. J Econ Entomol 2006; 99: 1590-1595.

59. Medeiros FP, Santos MA, Regis L, Rios EM, Rolim NPJ. Development of a Bacillus sphaericus tablet formulation and its evaluation as a larvicide in the biological control of Culex quinquefasciatus. Mem Inst Oswaldo Cruz 2005; 100: 431-434.

60. Khyami-Horani H, Katbeh-Bader A, Mohsen ZH. Isolation of endospore-forming bacilli toxic to Culiseta longiareolata (Diptera: Culicidae) in Jordan. Lett Appl Microbiol 1999; 128: $57-60$.
61. Darriet F, Hougard JM. An isolate of Bacillus circulans toxic to mosquito larvae. J Am Mosq Control Assoc 2002; 18: 65-67.

62. Shida O, Takagi H, Kadowaki K, Yano H, Komagata F. Differentiation of species in the Bacillus brevis group and the Bacillus aneurinolyticus group based on the electrophoretic whole-cell protein pattern. Antonie Van Leeuwenhoek 1996; 70: 31-39.

63. Das K, Mukherjee AK. Assessment of mosquito larvicidal potency of cyclic lipopeptides produced by Bacillus subtilis strains. Acta Trop 2006; 97: 168-173.

64. Geetha I, Manonmani AM, Paily KP. Identification and characterization of a mosquito pupicidal metabolite of a Bacillus subtilis subsp. Subtilis strain. Appl Microbiol Biotechnol 2010; 86: $1737-1744$.

65. Achard ME et al. An antioxidant role of catecholate siderophores in Salmonella. Biochem J 2013; 454: 543-9.

ID: 101610675) indexed and abstracted in EMBASE(Elsevier), SCIRUS(Elsevier),CABI, CAB Abstracts, Chemical Abstract Services(CAS), American Chemical Society(ACS), Index Copernicus, EBSCO, DOAJ, Google Scholar and many more. For further details, visit 